Discussion Paper No. 841

\title{
PROCRASTINATORS AND \\ HYPERBOLIC DISCOUNTERS: \\ PROBABILITY OF TRANSITION \\ FROM TEMPORARY \\ TO FULL-TIME EMPLOYMENT
}

\author{
SunYoun Lee \\ Fumio Ohtake
}

May 2012

The Institute of Social and Economic Research

Osaka University

6-1 Mihogaoka, Ibaraki, Osaka 567-0047, Japan 


\title{
Procrastinators and hyperbolic discounters: Probability of transition from temporary to full-time employment
}

\author{
SunYoun Lee ${ }^{\mathrm{a}^{*}}$, Fumio Ohtake
}

${ }^{a}$ Osaka School of International Public Policy, Osaka University, Osaka 560-0043, Japan

${ }^{\mathrm{b}}$ Institute of Social and Economic Research, Osaka University, Osaka 567-0047, Japan

Keywords: time preferences, temporary employment, ATT estimation

JEL Classification: D03, D90, J01

* Correspondence: International Public Policy, Osaka University, 1-31 Machikaneyama, Toyonaka, Osaka, 560-0043 Japan Tel (Fax): 81-6-6879-8572. E-mail: s-lee@osipp.osaka-u.ac.jp 
Abstract

Temporary agency work (TAW) is believed to facilitate the matching between firms and on-the-job searchers. This leads to shortening of the unemployment and job search duration. On the other hand, firms that hire temporary workers have less incentive to train them, which makes it difficult for low-skilled temporary workers to find a better job in future. Current literature has not established whether TAW employment improves the welfare of either or both the employers and employees. Therefore, this paper examines the effect of TAW employment in the Japanese labor market on employment transitions focusing on individual time preferences. Investments in one's career involve a trade-off between immediate costs and later rewards, and thus, individual heterogeneity in time preferences may explain the behavioral patterns of labor force. We find that TAW employees have a tendency toward impatience and hyperbolic discounting. In addition, those who have held temporary job are less likely to move into full-time job positions, but no significant wage differences are observed. The strength of the negative effects on the transition probabilities declines over time but the significant effects remain over the following years. Our results indicate that TAW for employees in Japan is more likely to function as a "dead-end" rather than "stepping stone" toward stable full-time employment. 


\section{Introduction}

In standard economics, temporary work has been thought to enhance labor market efficiency (Autor, 2008). A temporary agency, which facilitates the matching between firms and on-the-job searchers, is believed to play a role in shortening unemployment spells and thus improving the welfare of both the employers and employees. Temporary work has therefore been expected to function as a "stepping stone" toward stable full-time employment (Guell and Petrongolo, 2007; Ichino et al., 2005; Malo and Munoz-Bullon, 2002). Temporary workers, however, receive less work-related training than their counterparts in permanent employment (Booth et al., 2002), and thus it becomes more difficult for them to find a better job in a stable position as time progresses (Autor and Houseman, 2010). Furthermore, long duration temporary contracts lead to a reduction in workers' average job search intensity (Kahn, 2009), which again lessens the chances of moving into a more stable employment status.

In this study, we majorly focus on the factor that determines the probability of engaging in temporary agency work (TAW) and the effect of past work experience in the TAW sector on the transition to a permanent position, everything else being equal. When examining the effects of TAW employment on job transitions, we pay attention to individual heterogeneity in time preferences that may affect career paths. Specifically, we predict that behavioral patterns of employees concerning short-term and long-term impatience explain the probability of entering the TAW sector, which further significantly affects the probability of moving into full-time jobs and the wage differentials between those who have work experience in the TAW sector and those who do not.

The effects of time preferences on career consequences have been widely examined as the investments in one's career involves a trade-off between immediate costs and later rewards. Notably, the exit rate from unemployment status is affected by the degree of patience, which varies by the assumptions of exponential and hyperbolic discounting (DellaVigna and Paserman, 2005; Paserman, 2008). Impatient agents with exponential time preferences tend to lower the reservation wage, and this may increase the exit rate from unemployment. Hyperbolic agents, in contrast, are likely to defer job search activities and may not lower the level of reservation wages when they finally search for a job, leading to a longer duration of unemployment. Job-to-job transitions involving internal job promotions and external job mobility are also explained by individual time preferences, although it is yet to be established how exponential and/or hyperbolic discounting affects job mobility (Drago, 2006; van Huizen, 2010). 
Our paper empirically examines the long-term welfare of temporary workers in Japan, mainly focusing on the following: i) investigation of the relationship between time preferences and the probability of engaging in the TAW sector; and ii) examination of the probability of TAW workers moving into full-time regular employment and the differences in wages between workers who have held a temporary job and those who have not. The remainder of this paper is organized as follows. Section 2 explains the theoretical background of time preferences that affect individual behaviors and describes TAW employment in the Japanese labor market. Section 3 introduces the data and how we constructed the main variables regarding time preferences. Section 4 presents the econometric framework and section 5 reports the estimates of the average treatment effect on the treated (ATT). This paper may clarify the behavioral characteristics of TAW employees and their employment transition dynamics in the Japanese labor market.

\section{Time discounting}

\subsection{Discount function}

A decision maker is assumed to maximize utility over intertemporal choices using a discounted utility model. The intertemporal utility function of preferences can be expressed as the individual's well-being at time $t+k\left(\mathrm{u}_{\mathrm{t}+\mathrm{k}}\right)$ multiplied by his/her discount function $\left(\delta^{k}\right)$ (Paul, 1937). The discount function $\left(\delta^{k}\right)$ is further expressed by the discount rate $(\gamma)$, the individual's pure rate of time preference, and it is often interpreted as the relative weight attached at time $t$ to each individual's well-being at time $t+k$. The value of each subsequent period decreases at a constant rate, which is referred to as exponential discounting.

$$
\mathrm{U}^{\mathrm{t}}\left(\mathrm{u}_{\mathrm{t}}, \mathrm{u}_{\mathrm{t}+1} \ldots, \mathrm{u}_{\mathrm{T}}\right)=\sum_{\mathrm{k}=0}^{\mathrm{T}-\mathrm{t}} \delta^{\mathrm{k}} u_{t+k}, \text { where } \delta^{k}=\left(\frac{1}{1+\gamma}\right)^{\mathrm{k}}
$$

A potential problem of the exponential discounting rate model is that a person may not have well-formed plans about costs and benefits and display inconsistent time preferences. In order to allow for time inconsistency, quasi-hyperbolic discounting models have been proposed as an alternative to the standard exponential model (Laibson, 1997).

$$
\mathrm{U}^{\mathrm{t}}\left(\mathrm{u}_{\mathrm{t}}, \mathrm{u}_{\mathrm{t}+1} \ldots, \mathrm{u}_{\mathrm{T}}\right)=\mathrm{u}_{\mathrm{t}}+\beta \sum_{\mathrm{k}=1}^{\mathrm{T}-\mathrm{t}} \delta^{k} u_{t+k}, \text { where } 0<\beta<1
$$


In this model, the $\beta$ parameter is newly introduced; if $\beta$ equals one, it is equivalent to the exponential discounting function (1). The implied discount factor from the current to the subsequent period is $\beta \delta$, while the discount factor in the sufficiently distant future is simply $\delta$. In other words, the per-period discount rate between the current and the subsequent period is $\frac{1-\beta \delta}{\beta \delta}$ and the per-period discount rate between any two distant future periods is $\frac{1-\delta}{\delta}$. The former is higher than the latter, and it implies that agents prefer a larger reward in the sufficiently distant future over a smaller one at the moment. These hyperbolic agents with inconsistent time preferences are likely to face a high degree of short-term impatience again, when the distant future comes near.

The exponential discounting parameters $(\delta)$ capture time-consistent, long-term impatience and the hyperbolic discounting parameters $(\beta)$ capture time-inconsistent, short-term impatience. As presented in equations (1) and (2), when $\beta=1$, agents' $(\beta, \delta)$ preferences are time consistent and capture the standard discounted utility model, and when $\beta<1$, agents' $(\beta, \delta)$ preferences follow a quasi-hyperbolic time discounting function. Hyperbolic discounting is the most-studied discount utility anomaly. Another feature of inconsistent time preferences, which is contradictory to the standard model of discounted utility wherein the discount rate should be the same despite the types of intertemporal choices, is the "sign effect." The discount rates for gains are known to be higher than those for losses of the same magnitude (Thaler, 1981); for example, people are reluctant to borrow and favor a lower interest rate for borrowing than for saving.

\subsection{On-the-job search and job-to-job transitions}

The effects of time preferences have been examined on on-the-job searches by the unemployed (DellaVigna and Paserman, 2005) and job-to-job transitions, including internal promotions and external job mobility (Drago, 2006; van Huizen, 2010). In standard economic models of on-the-job searches, under which agents are assumed to discount future costs and benefits exponentially, individuals with higher discount rates tend to be impatient. Impatience has two inconsistent effects on job search effort and reservation wage decision. While impatient agents are more likely to accept the job offer despite low wages and exit unemployment, they prefer to avoid the immediate costs and defer job search activities (DellaVigna and Paserman, 2005). The effect of impatience on job search varies by the assumption of exponential and hyperbolic time preferences. If time preferences are constant over time, the reservation wage effect works more strongly than the search effect, thereby leading to an increase in the 
unemployment exit rate. If agents have hyperbolic time preferences, however, the search effect dominates the reservation wage effect, and thus, they stay unemployed longer. In other words, hyperbolic agents, who are more sensitive to the immediate costs of an employment search, are likely to delay their job search activities to a later period, such as writing the resume or contacting employers, and thus they are less likely to exit from unemployment.

As for the effects of time preferences on job-to-job transitions, Drago (2006) finds that patience is negatively related to external job mobility and positively to work effort; patient agents are more likely to stay in the same workplace and pursue the job promotion or position change, while impatient agents are more likely to switch jobs for better wages. These empirical results, however, may have some limitations associated with the assumptions and methodologies: the study assumes that career effort is exogenous and job search is characterized by immediate benefits; and it does not examine the impact of impatience on search behavior aside from its effect on job mobility. Taking these limitations into consideration, van Huizen (2010) finds the contrary result that patience has positive effects on both work and search effort, as predicted by the hyperbolic discounting model. It is explained that hyperbolic agents are likely to procrastinate both internal and external job mobility efforts because these both are investment activities involving immediate costs.

\subsection{TAW employment in Japan}

In Japan, a dual labor market comprised of a sector of highly stable employment and a considerably less stable sector of part-time, temporary contract workers has emerged since the 1970s and has become an important policy agenda, especially after the Lehman shock (Rebick, 2005; Okudaira et al., 2011). There has been some evidence of rigid mobility within the dual labor market that starting one's career in less stable rather than regular employment reduces one's probability of being in regular employment in the future (Ariga and Okazawa, 2011). Our data also suggest rigidity on job transitions between employment types (Appendix 2). On average, only $7.1 \%$ of employees who were in the TAW sector moved into permanent jobs over the past four years. Most part-time and dispatch workers remain in the same sector after one year and more. In particular, the mobility of male labor forces between sectors is less fluid than that of females. The persistence of the dual labor market leads to the conclusion that a temporary contract may act as a trap for long-term unstable employment.

In Japan, since the enactment of "The Worker Dispatch Law" in 1985, which allows project-based employment and the dispatching of temporary workers to demanders, the 
number of temporary workers has rapidly increased. After the Lehman shock in 1998, however, many temporary workers were laid off, and this has drawn the public's attention to the issue of unstable employment status and the need for legal protection. New rigid legislation was then enacted to impose a limitation on the contract term of temporary workers who are registered with TAW agencies and dispatched to manufacturing companies. The contract limitation excludes the TAW employees who are classified under the 26 professional categories that require company-specific knowledge and experience. The new legislation on TAW employment in Japan was formulated to assist temporary workers to become full-time stable employees after a certain period of work experience in the TAW sector. However, it may bring the unexpected outcome of temporary workers simply being laid off when their contract expires and rarely moving into permanent jobs.

\section{Data and methodology}

\subsection{Global COE Panel data}

The empirical analyses in this paper are based on data from a questionnaire survey titled "Preference and Life Satisfaction Survey," conducted in Japan. This is a panel survey that was started in February 2004 as part of the Osaka University 21st Century Center of Excellence Program. It has been conducted annually since 2004 using a random sample drawn from 6,000 individuals by a placement method. For the analysis on individual behavioral patterns of time preferences on TAW employment and its further effects on the probability of transition to permanent jobs, the survey data of 2009-2011 were used. However, since each year's questions concern present time preferences under the hyperbolic discounting function in a different way, we mainly used 2010 data to estimate the exponential and hyperbolic discounting parameters, and we used childhood time preferences to analyze the long-term effect on the probability of transition and wages over a four-year period.

\subsection{TAW employment}

The sample includes all labor force participants aged 20 or over. Our dataset enables us to identify the following employment types at the time of the survey: permanent employees (PE), temporary employees (TE), dispatched employees (DE), self-employed (SE), unemployed and persons who carry out job search activities (UE), and those who are not employed and do not look for jobs (NE). Students, retired persons, and housewives are dropped from the sample. Since TE and DE are hired on short-term 
contracts and their job turnovers are high, only those who are in the labor force at the time of the survey are observed; in other words, those whose contracts just expired around the time of the survey were not observed. The percentage of dispatched workers among the employed in 2010 is on average $1.72 \%$ (9.6 million out of 547.8 million) (Statistics Bureau, 2012), and this low percentage is reflected in our dataset; only $1.07 \%$ of the labor force $(42$ out of 3,938$)$ in the data is categorized into DE. With this small number of observations, examining the effect of TAW on the probability of moving into permanent jobs, when everything else is controlled, is not possible. Thus, to identify individuals in the TAW sector, we asked respondents whether they have ever been temporary employees over the past 2 years. TAW employees are defined as those who are registered with temporary agencies for a temporary assignment duration ranging from i) one day, ii) $2-10$ days, iii) 10 days -3 months, to iv) more than 3 months.

The possible career progression of our sample can be presented with multiple career paths (Appendix 1). Before respondents ever held temporary work, they were either unemployed or employed; after their experience in the TAW sector, they became permanent employees or other types of employees. Those who did not have any jobs before the TAW employment could have taken a job offer from the TAW sector or remain jobless. Those who already had jobs, on the other hand, could have pursued promotions or a position change, or quit their jobs and taken temporary work until they could find other jobs offering higher wages. If the analysis is based on the premise that some of the unemployed take temporary work and the others remain jobless, these subjects may display similar behavioral patterns concerning the job search and reservation wage of the unemployed predicted by exponential and hyperbolic discounting, as examined by DellaVigna and Paserman (2005). In addition, if we can assume that some of the employed continue working for the same employer, and the others quit their jobs and take temporary jobs until they find better jobs, these subjects may have hyperbolic discounting characteristics, as found by van Huizen (2010). However, our data have limitations in examining these on-the-job search and job mobility effects from a time preference perspective, as shown in the previous research, because the employment type of subjects whose short temporary contracts are expired are not clarified during the two-year period. Despite these limitations, because individual decisions on career paths, including whether to take temporary jobs, involve a trade-off between immediate costs and delayed rewards, we need to control for individual heterogeneity in intertemporal choices. Thus, this study predicts that individual time preferences and differences in the degree of patience between the near and distant future explain the probability of becoming TAW employees and moving into 
permanent jobs afterward.

\subsection{Measure of time preferences}

We use the responses to questions concerning time preferences to construct the main independent variables that affect the probabilities of becoming TAW employees and subsequently have a negative effect on the transition to full-time employment. To measure the discount rate and hyperbolic discounting "during childhood," we used the responses indicated on a five-point scale to the following questions: "When did you work on your summer vacation homework?" and "When did you plan to do it?" The scale ranged from 1 for the end of the vacation to 5 for the beginning of the vacation. Agents who have a preference for delayed rewards over immediate costs to finish the assignment are likely to procrastinate their homework during childhood. Thus, they allocate more effort to finish the assignment rather than pursue the short-term rewards. In other words, the lower the long-term discount factor $\delta$ and short-term discount factor $\beta$, the more subjects care about the immediate costs compared with the distant rewards.

We also constructed proxies for the "present" time discounting using the responses to the hypothetical question stated below. The present time preferences may be inversely correlated with the probability of having TAW experience because people would display hyperbolic characteristics because of their experience in the TAW sector. On the other hand, individual time preferences during childhood change because of education and/or work experience, and in that case, the present discounting factor reflects one's actual time preferences that affect the individual decision on career paths. Thus, we control individual time preferences using both childhood and present time discounting factor. We asked the respondents to choose between two options concerning intertemporal choices. A single choice between two intertemporal options only reveals an upper or lower bound on the discount rate. To identify the discount rate more precisely, we present subjects with a series of choices that vary the hypothetical rewards over seven days.

\section{[Hypothetical Question]}

"Let's assume that you are required to spend time cleaning a park. You need to spend two hours today AND next week. It seems that the litter in the park will decrease more than expected, so the number of hours you need to clean will be less. To account for this change, you have the option to shorten the hours by one hour today or shorten some hours in 7 days. Compare the hours and timing below in Option "A" with Option " $\mathrm{B}$ " and indicate for each 
row which option you prefer."

\begin{tabular}{l|l|l|cc}
\hline & $\begin{array}{l}\text { Option “A” } \\
\text { (Shorten today) }\end{array}$ & $\begin{array}{l}\text { Option "B" } \\
\text { (Shorten in 7 days) }\end{array}$ & \multicolumn{2}{c}{ Circle Option "A" or "B" } \\
\hline 1 & 1 hour & 50 minutes & A & B \\
\hline 2 & 1 hour & 1 hour & A & B \\
\hline 3 & 1 hour & 1 hour 5 minutes & A & B \\
\hline 4 & 1 hour & 1 hour 10 minutes & A & B \\
\hline 5 & 1 hour & 1 hour 15 minutes & A & B \\
\hline 6 & 1 hour & 1 hour 20 minutes & A & B \\
\hline 7 & 1 hour & 1 hour 30 minutes & A & B \\
\hline 8 & 1 hour & 2 hours & & \\
\hline
\end{tabular}

If a respondent chooses option $\mathrm{A}$, which shortens the time by 1 hour today but by no time in 7 days rather than option $\mathrm{B}$, which shortens the time by 50 minutes in 7 days but by no time today, the respondent is supposed to clean for 1 hour today and 2 hours a week later. The respondents would choose an option that they think would provide more favorable conditions. We expected that many respondents would choose option A at the beginning because the total shortening of time of option $\mathrm{A}$ is longer than that of option $B$, but eventually switch to option " $B$ " at a certain point when they feel indifferent between options A and B over two different time periods. Those with a higher discount rate would not change to option $\mathrm{B}$ until a shortened time in 7 days is substantially longer than that of today.

From each question, we computed the discount rate of each row $(\gamma): t_{A}=\left(\frac{1}{1+\gamma}\right) t_{B}$, where $t_{A(B)}$ is the length of the shortened time of option A (B). Then the discount rate of an individual is computed by estimating a log-normal distribution for the discount rate's $\log (1+\gamma)$ of options (Kimball et al., 2008). For example, if the respondent selects option A for the first 3 rows and switches to option B in the $4^{\text {th }}$ row, then $\log (1+\gamma)$ is computed from a log-normal distribution of the discount rate of the $3^{\text {rd }}$ and $4^{\text {th }}$ row. Then, we converted the discount rates $(\gamma)$ to the discounting factors $(\delta)$ by taking the exponential of the discounting rates and inversing the values $(\delta=(1 /(1+\gamma))$. The discount factor for the near future $(\beta \delta)$ is constructed from the intertemporal choices between today and 7 days, and the discount factor for distant futures $(\delta)$ is constructed from the same choices with difference time sets-90 days versus 97 days. Next a proxy for the hyperbolic discounting parameter $(\beta)$ is calculated by the ratio of $\beta \delta$ to $\delta$. 
Someone who currently prefers immediate rewards over future benefits but who suspects that they will have the same preferences in the distant future, might attempt to choose avoiding the immediate rewards in the distant future choice sets. These hyperbolic agents doubt that their preferences will change over time and eliminate an option that seems inferior now but might attract them later.

\section{The econometric framework}

\subsection{Notation}

The ATT attempts to reduce the bias in the estimation of treatment effects with non-randomized observational data sets. To estimate the actual effect of a treatment on the potential outcome of an individual, Rosenbaum and Rubin (1983) proposed the propensity score matching method (PSM), which compares outcomes performed by treated and control subjects who are as similar as possible. The average treatment effect of the program is then calculated as the mean difference in outcomes across the treated group and the statistical counterfactual group that has similar observed characteristics to those of the treated group.

To estimate how treated agents would have performed if they had not received the treatment, the untreated agents that have similar characteristics are substituted for the counterfactual group. The PSM approach is used to construct this unobserved or counterfactual group. In case of a binary treatment, the treatment indicator T equals one if individual $i$ receives treatment and zero otherwise, and $\mathrm{X}$ is the multidimensional vector of pre-treatment characteristics. The potential outcomes are then defined as $Y_{i}\left(T_{i}\right)$ for each individual $i$, where $i=1, \ldots, \mathrm{n}$. The average treatment effect of an individual $i$ can be estimated as follows:

$$
\begin{gathered}
\mathrm{E}\left[Y_{i}(1)-Y_{i}(0) \mid T_{i}=1\right]=\mathrm{E}\left[E\left(Y_{i}(1)-Y_{i}(0) \mid T_{i}=1, \mathrm{p}(\mathrm{X})\right]\right. \\
\quad=E\left(E\left[Y_{i}(1) \mid T_{i}=1, \mathrm{p}(\mathrm{X})\right]\right)-E\left(E\left[Y_{i}(0) \mid T_{i}=1, \mathrm{p}(\mathrm{X})\right]\right)
\end{gathered}
$$

The potential outcome of the treated group who has not received the treatment $\left(\mathrm{E}\left[Y_{i}(0) \mid T_{i}=1\right]\right)$ is not observed. What is actually observed is $E\left[Y_{i}(0) \mid T_{i}=0\right]$ but it may not be a good alternative because the group without the treatment would have an outcome different from that with treatment regardless of the treatment effect; this is known as selection bias. A proper substitute for this counterfactual group is the untreated agents who are similar to the treated agents and are found on the basis of the probability of taking treatment given a vector of observed variables. The fact that only inside the range of the observed data points is extrapolated is different from ordinary 
regression.

\subsection{PSM methods}

To validate the PSM methods, the following two assumptions should be satisfied. First, given a set of observable covariates $X$ that are not affected by treatment, the outcomes $\mathrm{Y}_{i}^{C}$ of the control group should be independent of treatment assignment $\mathrm{T}$. This assumption is called "conditional independence" or "unconfoundedness": $\mathrm{Y}_{i}^{C} \perp T_{i} \mid \mathrm{X}_{i}$. For a given propensity score, exposure to treatment-work experience as TAW employees over the past 2 years-should be random and therefore treated and control groups differ only in their error term, which is approximately independent of X. The probability of transition to permanent employment of the control group should not influence the choice of the individual to engage in the TAW sector over the past 2 years.

A second condition, called "common support," ensures that there are sufficiently large observations in the overlapped region of propensity score distribution: $\mathrm{P}\left(T_{i}=1 \mid X_{i}\right)<1$. The substantial region of propensity score distribution should be overlapped between those who have two years of experience of TAW employment and those who do not. The overlap condition for individuals with the same $x$ value in $\mathrm{X}$ are allowed to have a positive probability of being in treated and control groups.

When the two assumptions hold, the balancing hypothesis that observations with the same propensity score must have the same distribution of (un)observable characteristics independently of treatment status is tested. The test is repeated until the means of each characteristic are equal for treated and control units in all intervals of the propensity score. If the means of one or more characteristics are unequal, the balancing properties are unsatisfied and a better parsimonious specification of the covariates is required. If treatment and control groups with the same propensity score are identically distributed, the ATT model is established using the PSM estimator.

$$
\tau_{A T T}^{P S M}=E\left[Y_{i}^{T} \mid T_{i}=1, P(X)\right]-\mathrm{E}\left[Y_{i}^{C} \mid T_{i}=1, P(X)\right]
$$

We use a stratified nearest-neighbor matching algorithm that matches treatment and control cases on the closest propensity score. C(i) denotes the set of control units matched to the treated unit $i$ with an estimated value of the propensity score of $p_{i}$. The nearest neighbor matching set is $\mathrm{C}(\mathrm{i})=\min _{j}\left\|p_{i}-p_{j}\right\|$. More explicitly, with cross-section data and within the common support, the treatment effect can be written as follows (see Heckman et al., 1997; Smith and Todd, 2005):

$$
\tau_{\mathrm{PSM}}=\frac{1}{\mathrm{~N}_{\mathrm{T}}} \sum_{\mathrm{i} \in \mathrm{T}}\left[\mathrm{Y}_{\mathrm{i}}^{\mathrm{T}}-\sum_{\mathrm{j} \in \mathrm{C}(\mathrm{i})} \omega_{i j} \mathrm{Y}_{\mathrm{j}}^{\mathrm{C}}\right]
$$




$$
\begin{gathered}
=\frac{1}{N_{T}}\left[\sum_{i \in T} Y_{i}^{T}-\sum_{i \in T} \sum_{j \in C(i)} \omega_{i j} Y_{j}^{C}\right] \\
=\frac{1}{N_{T}} \sum_{i \in T} Y_{i}^{T}-\frac{1}{N_{T}} \sum_{j \in C(i)} \omega_{j} Y_{j}^{C}
\end{gathered}
$$

$\mathrm{N}_{\mathrm{T}}$ is the number of participants $\mathrm{i}$ and $\omega_{i j}$ is the weight used to aggregate outcomes for the matched nonparticipants $\mathrm{j}: \omega_{i j}=\frac{1}{N_{i}^{C}}$ if $j \in \mathrm{C}(\mathrm{i})$ and $\omega_{i j}=0$ otherwise.

\section{Results}

\subsection{Descriptive statistics}

The number of people who have ever held temporary work in 2010 is $7.2 \%$ (Table 1). The sample used for the analysis includes all persons classified as employed and unemployed. Approximately half of the samples have been hired as permanent full-time employees at the time of survey collection, of which $3.4 \%$ answered that they have experience working as temporary workers over the past two years. Table 2 shows average individual characteristics and time preferences variables, which were collected from the same questionnaire for both the treated and control groups from the same Japanese labor market. The observable characteristics of the treated and control groups, which are balanced on the basis of the observed variables, are very similar and the differences between the treated and control groups are smaller than between the treated and the entire control group.

Time preference variables indicate that individuals with TAW experience have a tendency for procrastination or impatience, and they have a lower (higher) discount factor (rate) and a lower hyperbolic discounting parameter. This suggests that TAW employees are likely to be impatient and have inconsistent time preferences. The last columns of Table 2 reveal that the treated group with the TAW experience shows potentially lower earnings and more limited employment opportunities to move into permanent jobs in the future. The important questions addressed in this study are, when all observatory variables are held constant, whether those who have ever held temporary work remain in the informal sector or move into permanent jobs and whether the earnings of individuals who have work experience in the TAW sector are statistically different from those who do not. 


\subsection{Effects of behavioral characteristics}

The propensity score was predicted from a logistic regression of TAW employment on individual characteristics such as income, age, assets, marital status, number of children, and educational backgrounds (Table 3). Models (1) and (2) are controlled by childhood time preferences imputed from summer vacation homework (see Table 1). Models (3) and (4) use the present time preferences computed from the hypothetical question about cleaning a park.

Models (1) and (3) estimate exponential discounting parameters when $\beta$ equals 1 , and models (2) and (4) present hyperbolic discounting parameters given the same $\beta$. Time preferences may play a significant role in identifying the behavior of subjects who have been in the TAW sector compared with other types of employees, ceteris paribus: i) exponential discounting parameters $(\delta)$ are negatively correlated to TAW employment but the childhood discounting parameter has no significant effect; ii) the degrees of hyperbolic discounting parameters $(\beta)$, with the same discount factors $(\delta)$, have significant negative effects in our model. Including the hyperbolic discounting parameters $(\beta)$ in the model, which capture time-inconsistent and short-term impatience, improves the explanatory power of the model, and their effects on TAW employment are significant given the long-term impatience parameters $(\delta)$. This implies that the models support the hyperbolic discounting function, whereby discount rates are not constant but declining.

Although these results should be interpreted with caution, they may suggest that agents who prefer immediate pay despite potential long-term loss caused by unstable, temporary types of employment have a high probability of working in the TAW sector. This includes subjects that were either unemployed or employed before they had taken the TAW work. The then unemployed would have found more stable, permanent jobs if they had dedicated more time and energy in searching for jobs that adequately engage their capabilities, while the then employed may have received internal promotions if they had not quit and taken temporary work. Our findings that TAW employment is related to hyperbolic discounting parameters ( $\beta$ ) may imply that agents have inconsistent time preferences over intertemporal choices.

A significant role of behavioral characteristics is also found concerning the balancing property when PSM are employed. When we predict the propensity property without controls for time preferences, the balancing property is not satisfied and a different specification of the propensity score needs to be considered. In other words, without time preference variables, the model fails to find the control groups that are distributed identically throughout all blocks. This suggests that time preference 
characteristics contribute to identifying the significant differences between those who have work experience in the TAW sector and those who do not.

Besides the discount parameters, Table 3 presents parameters of other observed characteristics. Agents who have less financial assets, are not married, and women are more likely to enter the TAW sector. The sign effect does not appear to be significant concerning whether the individual has held temporary work but it controls one feature of the discounted-utility anomaly and improves the explanatory power of the models. With the controls of individual characteristics and sign effect, agents' time preferences appear to have significant effects on the probability of engaging in the TAW sector: hyperbolic agents may have a higher probability of becoming temporary workers. For the labor force in the TAW sector, it may gain immediate rewards from earnings but lose the chance to obtain a more stable job if TAW employment has a negative effect on the probability of transition to full-time employment. However, if TAW employment acts as a spring board, the gains and losses may work in opposite ways.

\subsection{Impact of TAW employment experience: Transition probability \& wages}

By the PSM methods, the closest group that has similar observatoary characteristics was found, and the treated and control groups are approximately balanced on the variables predicting the propensity score. The density distributions of the propensity scores are found in Figure 1. The bottom-half of the graph shows the propensity scores distribution for the non-treated, while the upper-half refers to the treated individuals. This figure presents the existence of a substantially overlapped propensity distribution between the treated and the untreated. The effects of TAW employment on the probability of transition to permanent employment and wage differences are reported in Table 4.

Row (i) shows a base model that includes no observatory characteristics when predicting the propensity score and further estimating the ATT. The following rows (ii) and (iii) include the behavior patterns of impatience (Table 3: model (2) of PSM) and time inconsistency (Table 3: model (4) of PSM), as well as the individual characteristics explained in section 5.1. In all cases, we found that the experience in TAW employment has a significant negative effect on the probability of moving into a stable job. When confounding variables are properly controlled, the effects of the TAW employment on the transition probability are still negatively significant. Those who have experience working in the TAW sector have a significant and negative effect of 26 (or 31) percentage points on the probability of becoming permanent employees in comparison with those who have the same observatory characteristics but do not have work 
experience in the TAW sector.

Table 4 also reports the TAW employment effects on wages with the same structure as the transition probability. With no controls for individual characteristics, it seems that the TAW employment experience has a significant negative effect on the hourly wage. When the individual behavioral characteristics are controlled, however, the statistical significance disappears. This is different from the case of the transition probability, which shows significant negative correlations with the TAW experience even when the confounding variables are controlled. The TAW experience may defer the agents from moving into a more stable job but it does not necessarily mean that their wages are significantly lower than those for the other types of employees. It is possible that project-based workers or seasonal workers who are hired on a contingency basis do not earn less than other types of employees for the time being, but the wage gap may widen in the long run.

\subsection{Long-term impact of the TAW employment experience}

To observe the long-term effects on the transition probability and wages, we ran a regression to estimate the effect of TAW employment at the time of survey $(t)$ on the probability of transition to permanent employment and hourly wages after one to three years $(t+1, t+2, t+3)$. The comparison of each subsequent period allows us to observe the change in the strength of the effects over time. The effect of the TAW experience on wages is not statistically significant in either the long term or the short term (Table 5). There is a possibility that the negative effect on wages between TAW and permanent employees may be shown after a much longer period of time, but at least within 3 years such effects are not observed in our data.

In case of transition probability models, however, the effects decrease in the following years but still remain statistically significant. Those who have ever had past work experience in the TAW sector had difficulty achieving stable employment in the following years. The findings that experience working as TAW employees has a negative effect in Japan may be explained by the characteristics of the rigid Japanese labor market: the transition to other employment types is difficult and any experience of being hired as TAW workers in the past might provide negative signals to potential employers in Japan.

\subsection{Robustness test \& unmeasured bias}

Our research interest lies in those who are involuntarily in the TAW sector but have attempted to move to permanent jobs. One may question the presence of individuals, 
more likely women, who select the TAW employment type for better work-life balance despite the unstable status and lower wages. Regardless of gender, older cohorts approaching retirement age may have a lower probability or less incentive to move into the primary sector. To investigate whether gender and age differences have a significant effect on the transition probability, we examine the effect of TAW employment with the sample grouped by sex and by different age ranges: younger cohorts aged less than 40 , the median age (52), and retirement age (60) (Table 6).

The results indicate that being in the TAW sector decreases an individual's probability of being in permanent employment and its significant negative effects remain even when the sample is grouped by gender or age. In particular, with the controls for the present time preference characteristics, the significant negative effects appear to be constant over all ranges of age. The effect of TAW employment on hourly wages, on the other hand, is not found to be significant in the whole sample. The effects with a restricted sample by gender or age are also not observed, and in addition, the sign of the effects are not consistent. The restricted samples who are males and older than the retirement age and have held temporary work have a probability of earning less but they are not significant at the $10 \%$ significance level. The specification requires careful interpretation when the sample becomes too small: for example, the sample aged 60 and over or those aged 40 and less.

\subsection{Sensitivity Analysis}

Propensity-score matching estimators are not consistent estimators for treatment effects if unobserved variables that affect the assignment process are also related to the outcomes. In order to estimate the extent to which such "selection on unobservables" may bias the probability of moving into a stable permanent job, we use Rosenbaum's (2002) procedure for bounding the treatment effect estimates (see Becker and Caliendo, 2007). If there is a hidden bias, two individuals with the same observed covariates $x$ have different chances of receiving treatment. The odds that individuals receive treatment are then given by $\frac{\mathrm{P}_{\mathrm{i}}}{1-\mathrm{P}_{\mathrm{i}}}$ and $\frac{\mathrm{P}_{\mathrm{j}}}{1-\mathrm{P}_{\mathrm{j}}}$, and the odds ratio is as follows:

$$
\frac{P_{i} /\left(1-P_{i}\right)}{P_{j} /\left(1-P_{j}\right)}=\frac{P_{i}\left(1-P_{j}\right)}{P_{j}\left(1-P_{i}\right)}=\frac{\exp \left(\beta x_{i}+\gamma u_{i}\right)}{\exp \left(\beta x_{j}+\gamma u_{j}\right)}=\exp \left\{\gamma\left(u_{i}-u_{j}\right)\right\}
$$

If both units have identical observed covariates-as implied by the matching procedure - the $x$ vector cancels out. To have no hidden bias, $\mathrm{u}_{\mathrm{i}}$ should be equal to $\mathrm{u}_{\mathrm{j}}$, implying that there are no differences in unobserved variables, or $\gamma$ should be zero, implying no influence of unobserved variables on y. Rosenbaum (2002) shows that the 
equation implies the following bounds on the odds ratio that either of the two matched individuals will receive treatment: $\frac{1}{\mathrm{e}^{\gamma}} \leq \frac{\mathrm{P}_{\mathrm{i}}\left(1-\mathrm{P}_{\mathrm{j}}\right)}{\mathrm{P}_{\mathrm{j}}\left(1-\mathrm{P}_{\mathrm{i}}\right)} \leq \mathrm{e}^{\gamma}$.

Since transition probabilities are binary outcomes, we use the Mantel-Haenszel (1959) test statistic proposed by Aakvik (2001). The results are presented in Table 7. The $Q+\mathrm{MH}\left(Q^{-\mathrm{MH}}\right)$ statistic adjusts the $\mathrm{MH}$ statistic downward for positive (negative) selection. If $\mathrm{e}^{\gamma}=\Gamma=1$, it means both matched individuals have the same probability of engaging in the TAW sector. If both $Q+\mathrm{MH}$ and $Q-\mathrm{MH}$ statistics are significant, the estimators are robust against the unobserved factors. In other words, there appears to be no hidden bias that influences the assignment into treatment.

As for the upper bounds under the assumption that we have overestimated the treatment effect, the significance levels on all bounds are less than the 0.01 level. This indicates that the study is insensitive to the upward bias. Given the negative estimated treatment effect, the bounds under the assumption of underestimation deserve more attention. With the value of $\Gamma=2$, the result remains significant at the $1 \%$ level and $Q_{m h}^{-}$is on the decrease but still significant at the $10 \%$ level (summer vacation homework) and 5\% level (cleaning a park). This suggests that negative selection bias does not occur. Since an unmeasured variable does not appear to cause the odds of receiving the treatment to differ between the treatment and comparison groups, the confidence intervals for the effect of TAW employment on the transition to permanent jobs seem reliable.

Regarding the effects of the TAW employment on hourly wages, which are continuous variables, we check the Rosenbaum bounds (Table 8). Without any controlled observatory characteristics, TAW experience seems to have a significant negative effect on hourly wage, but we could not find any significant short-term and long-term effects when individual characteristics and time preferences were held constant. Regarding the negative selection bias, when the value of $\Gamma$ reaches 1.1 or higher, the significance levels decline and become less than 0.01 . This implies that a downward bias in the estimated treatment effects does not happen, but the significance values under the assumption of overestimation indicate that the effects may be overestimated. This indicates that individuals who are most likely to become TAW employees tend to have higher hourly wages even without treatment, given that they have the same observatory characteristics as the individuals in the comparison group.

\section{Concluding Remarks}

There are both positive and negative views about TAW employment. From a 
positive perspective, temporary contracts are believed to avoid labor inflexibility to some extent. For firms, it provides a compelling incentive to utilize TAW employees as a buffer stock of employment or for leave replacement. As for employees, TAW could act as stepping stones to permanent employment in good jobs. On the other hand, the low levels of retention and motivation, the lack of opportunities for career advancement, lower satisfaction in certain job components, and less work-related training are thought to be very negative aspects of TAW, because they act as deterrents to workers moving into full-time regular employment. These characteristics may lead to a longer duration of TAW employment once they are hired as temporary workers.

We examined whether TAW employment is explained by individual heterogeneity in intertemporal choices and whether the TAW experience has a negative or positive effect on the probability of moving into a permanent job and wages in the long run. Due to the several career paths available before, after, and during the experience in the TAW sector for the past 2 years, we may not have accurately defined the effects of time preferences on TAW employment from a time preference perspective. However, individual decisions on career paths including whether to take temporary jobs involve a trade-off between immediate costs and delayed rewards, and thus, time preferences may account for individual unobserved choice characteristics. The estimation results indicate that agents with TAW employment appear to have time inconsistent preferences and thus, they present higher discount rates in the near future than in the distant future. Another area of interest is the Average Treatment Effect on the Treated, or ATT, which measures the impact of experiencing TAW employment on transition probabilities and wages. The treated and control groups have identical distributions over a substantial range. The results estimated inside the range of the observed data points indicate that those who have ever held temporary work have a lower probability of moving into permanent jobs and the significant negative effect lasts a long time, although the effect sizes decrease as time progresses. On the other hand, wage differentials are not significant between those who have work experience as TAW employees and those who do not. The effects of TAW employment on wages remain insignificant over these periods.

With the available data, we are unable to accurately compare the impact of TAW employment before and after the enactment of the new legislation in 2010, because our most recent data collected in 2011 contain information on TAW experience during the period 2009-2010. We need further data containing respondents with TAW experience only after 2010 to compare with those with TAW experience before 2010. Although we cannot assure whether the effect of TAW experience during the period 2009-2010 stems 
from the enactment of the new legislation, the fact that TAW experience during the given period has a significant, larger, and negative effect on the probability of transition into permanent employment in 2011 implies that the negative effect might have been reinforced by the strict legislation. Then, one may question how the legislation correlates with the behavioral patterns of temporary workers.

A stricter legislation may play a role of making impatient, hyperbolic agents recognize their own self-control problems and driving then to pursue the long-run rewards with payment for the immediate costs. To be more specific, the level of sophistication versus naivety has tangible implications on public policy formulation and implementation. If the current TAW workers are sophisticated enough to pay for the immediate costs for the rewards accrued in the distant future, the strict legislation may act as a stimulus device for them to attempt for the stable jobs more eagerly than before. It could then lessen the number of people preferring short-run rewards, who otherwise would have become full-time workers with a better pay. However, if they are too naive, the prohibition on the dispatch work may discourage them from finding any kind of jobs from the first. In this case, the policies that educate and train people to find jobs that matches their abilities rather than stricken may contribute to the welfare of the employees. The further research with additional data is required to examine how hyperbolic agents who are more likely to engage in temporary work would behave after the enactment of the legislation.

To assess the robustness of matching estimators, we also examined whether there exist unobserved variables that affect assignment into treatment and the outcome variable simultaneously. We used the bounding approach suggested by Rosenbaum and the results indicate that we do not observe any effects caused by an unmeasured variable regarding the transition probability, and the effects are neither downward nor upward biased across all bounds. This shows that the inference in the regression results on transition probabilities would not change because of different values on unobserved factors despite being identical on the matched covariates. Because of the limited time period of our data, we were not able to accurately examine the long-term effect or the impact after the legislation enactment from time preferences' perspective. Nevertheless, the combined evidence that this study finds suggests that TAW for employees in Japan during the 2009-2011 time period is more likely to function as a "dead-end" rather than "stepping stone" toward stable full-time employment. 


\section{References}

Aakvik, A., 2001. Bounding a matching estimator: The case of a Norwegian training program. Oxford Bulletin of Economics and Statistics, 63, 115-143.

Ariga, K., Okazawa, R., 2011. The employment rigidity in Japan: its causes and consequences. Japan's Bubble, Deflation, and Long-term Stagnation, ed. by Hamada, K., Kashyap, A., \& Weinstein, D., Cambridge: MIT Press.

Autor, D. H., 2008. The economics of labor market intermediation: An analytic framework. National Bureau of Economic Research Working Paper Series, 14348.

Becker, S. O., Caliendo, M., 2007. Sensitivity analysis for average treatment effects. The Stata Journal, 1, 71-83.

Booth, A. L., Marco F., Jeff F., 2002. Temporary jobs: Stepping stones or dead ends?. The Economic Journal, 112, F189-F213.

Autor, D.H., Houseman, S.N., 2010. Do temporary-help jobs improve labor market outcomes for low-skilled workers? Evdience from "Work First." American Economic Journal: Applied Economics, 2, 96-128.

DellaVigna, S., Paserman, M. D., 2005. Job search and impatience. Journal of Labor Economics, 23, 527-588.

Drago, F., 2006. Career consequences of hyperbolic time preferences, (Institute for the Study of Labor (IZA)).

Guell, M., Petrongolo, B., 2007. How binding are legal limits? Transition from temporary to permanent work in Spain, Labour Economics, 14, 153-183.

Ichino, A., Mealli, F., Nannicini, T., 2005. Temporary Work Agencies in Italy: A Springboard Toward Permanent Employment?. Giornale degli Economisti e Annalidi Economia, 64, 1, 1-27.

Kahn, L., 2009. Temporary jobs and job search effort in europe. Institute for the Study of Labor (IZA).

Kimball, M. S., Sahm, C.R., Shapiro, M. D., 2008. Imputing Risk Tolerance from Survey Response. Journal of the American Statistical Association, 103(483), 1028-1038.

Laibson, D., 1997. Golden eggs and hyperbolic discounting. Quarterly Journal of Economics, 112(2), 443-477.

Malo, M.A., Munoz-Bullon, F., 2002. Temporary help agencies and the labor market biography: A sequence-oriented approach. Studies on the Spanish Economy, 132, FEDEA. 
Mantel, N., Haenszel, W., 1959. Statistical aspects of the analysis of data from retrospective studies. Journal of the National Cancer Institute, 22: 719-748.

Okudaira, H., Ohtake, F., Kume, K., Tsuru, K., 2011. What does a temporary help service job offer? Empirical suggestions from a Japanese survey. RIETI Discussion Paper Series, 11-E-077.

Paul, S., 1937. A note on measurement of utility. Review of Economic Studies, 40, 1-33

Paserman, M.D., 2008. Job search and hyperbolic discounting: Structural estimation and policy evaluation. The Economic Journal, 118, 1418-1452.

Rebick, M., 2005. The Japanese Employment System: Adapting to a New Economic Environment.Oxford: Oxford University Press.

Rosenbaum, P.R., 2002. Observational Studies. 2nd ed. New York: Springer.

Rosenbaum, P.R., Rubin, D.B., 1983. The Central Role of the Propensity Score in Observational Studies for Causal Effects. Biometrika, 70, 41-55.

Smith, J., and P. Todd (2005): "Does Matching Overcome LaLonde's Critique of Nonexperimental Estimators?,"Journal of Econometrics, 125(1-2), 305-353.

Statistics Bureau (2012). Labor force survey: Employee by type of employment. Retrieved February $\quad 5, \quad 2012$ from http://www.stat.go.jp/data/roudou/longtime/03roudou.htm.

Thaler, R., 1981. Some empirical evidence on dynamic inconsistency. Economics Letters, 8, 201-207

van Huizen, T., 2010. On-the-job search, work effort and hyperbolic discounting. Utrecht University School of Economics, mimeo. 
Table 1 Definitions of variables

\begin{tabular}{|c|c|c|c|c|}
\hline Variables & Definitions & obs & mean & s.d. \\
\hline $\begin{array}{l}\text { Summer vacation homework: } \\
\text { Proxy for exponential discounting } \\
(\delta)\end{array}$ & $\begin{array}{l}\text { Response to the question "When did you plan to do your homework assignments?" on a 5-point scale, } \\
\text { from } 1 \text { (at the end of the vacation) to } 5 \text { (at the beginning of the vacation). }\end{array}$ & 1664 & 3.977 & 0.958 \\
\hline $\begin{array}{l}\text { Summer vacation homework: } \\
\text { Proxy for hyperbolic discounting } \\
(\beta)\end{array}$ & $\begin{array}{l}\text { Using the responses to the question "When did you do your homework assignments?" on a 5-point } \\
\text { scales, from } 1 \text { (at the end of the vacation) to } 5 \text { (at the beginning of the vacation) and the responses to } \\
\text { the question as regards to when the subjects planned to do the homework explained above, the } \\
\text { hyperbolic discounting was constructed by dividing the second responses (action) by the first } \\
\text { responses (plan) or differencing from the first responses (plan) to the second responses (action). }\end{array}$ & 1664 & 0.708 & 0.323 \\
\hline $\begin{array}{l}\text { Cleaning a park: } \\
\text { Proxy for exponential discounting } \\
(\delta)\end{array}$ & $\begin{array}{l}\text { Responses to the question "Let's assume that you were required to spend time cleaning a park, and you } \\
\text { have the option to shorten the hours by one hour in } 90 \text { days or shorten some hours in } 97 \text { days" } \\
\text { Discounting rates for every choice computed and converted to discounting factors for the distant } \\
\text { future. }\end{array}$ & 1446 & 0.903 & 0.359 \\
\hline $\begin{array}{l}\text { Cleaning a park: } \\
\text { Proxy for hyperbolic discounting } \\
(\beta)\end{array}$ & $\begin{array}{l}\text { Comparing with discounting factors for the near future (today versus in } 7 \text { days), short-run impatience } \\
\text { is computed dividing discounting factor of the near future by discounting factor of the distant future. }\end{array}$ & 1352 & 1.026 & 0.246 \\
\hline Sign effect & $\begin{array}{l}\text { The difference in the discount rate imputed from receipt of } \$ 100 \text { tomorrow to the discount rate } \\
\text { imputed from payment of the same amount tomorrow. }\end{array}$ & 1827 & 0.002 & 0.077 \\
\hline $\begin{array}{l}\text { Household income (excluding } \\
\text { oneself) }\end{array}$ & Per-capita household income (excluding oneself) in million yen. & 1664 & 3.194 & 3.300 \\
\hline Age & Ages of repondents & 1664 & 48.011 & 10.959 \\
\hline Household property (Land / & Per-capita household property including lands and housings in million yen & 1664 & 18.747 & 20.636 \\
\hline Household financial assets & Per-capita household financial assets in million yen & 1664 & 11.231 & 15.882 \\
\hline Household Housing Loans & Per-capita household mortgages in million yen & 1664 & 6.181 & 8.901 \\
\hline Household other debts & Per-capita household debt holding other than mortgages in million yen & 1664 & 0.782 & 1.971 \\
\hline Number of children & Number of children at the time of survey & 1664 & 1.800 & 1.061 \\
\hline Married (=1) & A binary indicator for marrital status which equals 1 if married and 0 otherwise & 1664 & 0.808 & 0.394 \\
\hline Educational Level & $\begin{array}{l}\text { A continuous variable ranging from } 1 \text { (lower than middle school level)-5 (higher than graduate school } \\
\text { level) [Descriptive Stats: High school level] }\end{array}$ & 1664 & 0.460 & 0.499 \\
\hline Female $(=1)$ & A binary indicator for females which equals 1 for female repondents 0 otherwise & 1664 & 0.436 & 0.496 \\
\hline dispatched experience $(=1)$ & $\begin{array}{l}\text { A binary indicator which equals } 1 \text { if the respondent has ever held temporary work for the past } 2 \text { years } \\
\text { and } 0 \text { otherwise }\end{array}$ & 1664 & 0.072 & 0.259 \\
\hline PE (Permanet Employment) & $\begin{array}{l}\text { A binary indicator for employment status which equals } 1 \text { if respondents have permanent jobs and } 0 \\
\text { otherwise. }\end{array}$ & 1630 & 0.556 & 0.497 \\
\hline Hourly wage & $\begin{array}{l}\text { A continuous variable computed by a ratio of hourly/monthly/yearly wage to labor hours (Maximum } \\
\text { value is five hundred yen). }\end{array}$ & 1541 & 1713.990 & 2156.826 \\
\hline
\end{tabular}


Table 2 Descriptive statistics of treated and control groups

\begin{tabular}{|c|c|c|c|c|c|c|c|c|c|c|c|c|c|}
\hline & \multirow{2}{*}{ Variables } & \multicolumn{4}{|c|}{ Treated Group } & \multicolumn{4}{|c|}{ Matched Controls } & \multicolumn{4}{|c|}{ Matched Controls } \\
\hline \multirow{3}{*}{$\begin{array}{l} \\
\text { Summer Vacation } \\
\text { Homework }\end{array}$} & & Mean & S.E & Min & $\operatorname{Max}$ & Mean & S.E & Min & Max & Mean & S.E & Min & Max \\
\hline & Proxy for exponential discounting & 3.99 & 0.96 & 1 & 5 & 3.98 & 0.96 & 1 & 5 & 3.98 & 0.96 & 1 & 5 \\
\hline & Proxy for hyperbolic discounting & 0.65 & 0.34 & 0.20 & 2.00 & 0.71 & 0.32 & 0.20 & 2.00 & 0.71 & 0.32 & 0.20 & 2.00 \\
\hline \multirow{2}{*}{ Cleaning a Park } & Proxy for exponential discounting & 0.86 & 0.37 & 0.38 & 1.57 & 0.91 & 0.36 & 0.38 & 1.57 & 0.91 & 0.36 & 0.38 & 1.57 \\
\hline & Proxy for hyperbolic discounting & 1.00 & 0.15 & 0.24 & 1.85 & 1.03 & 0.26 & 0.24 & 4.16 & 1.03 & 0.25 & 0.24 & 4.16 \\
\hline $\begin{array}{l}\text { Gain \& Loss asymmetry } \\
\text { (Discount utility anomaly) }\end{array}$ & Sign Effect & -0.003 & 0.07 & -0.34 & 0.40 & 0.001 & 0.08 & -0.41 & 0.40 & 0.001 & 0.08 & -0.41 & 0.40 \\
\hline \multirow[t]{14}{*}{ Individual Characteristics } & $\begin{array}{l}\text { Household income (excluding oneself) } \\
\text { in million yen }\end{array}$ & 3.05 & 2.95 & 0 & 13.5 & 3.11 & 3.21 & 0 & 17 & 3.21 & 3.33 & 0 & 19.5 \\
\hline & Age & 47.158 & 11.855 & 22 & 74 & 47.782 & 10.885 & 21 & 75 & 48.077 & 10.887 & 21 & 75 \\
\hline & $\begin{array}{l}\text { Household property (Land / Housing) in } \\
\text { million yen }\end{array}$ & 17.63 & 20.32 & 0 & 100 & 17.58 & 18.98 & 0 & 100 & 18.83 & 20.66 & 0 & 100 \\
\hline & Household financial assets in million yen & 7.04 & 8.97 & 1.25 & 40 & 8.60 & 9.42 & 1.25 & 75 & 11.56 & 16.25 & 1.25 & 100 \\
\hline & Household Housing Loans in million yen & 4.9 & 8.0 & 0 & 30 & 6.3 & 8.9 & 0 & 30 & 6.3 & 9.0 & 0 & 30 \\
\hline & Household other debts in million yen & 0.76 & 1.95 & 0 & 10 & 0.77 & 1.92 & 0 & 10 & 0.78 & 1.97 & 0 & 10 \\
\hline & Number of children & 1.67 & 1.15 & 0 & 5 & 1.81 & 1.06 & 0 & 5 & 1.81 & 1.05 & 0 & 5 \\
\hline & Married (=1) & 0.69 & 0.46 & 0 & 1 & 0.82 & 0.39 & 0 & 1 & 0.82 & 0.39 & 0 & 1 \\
\hline & $\begin{array}{l}\text { Educational Level } 1 \text { (Junior high school } \\
\text { and lower) }\end{array}$ & 0.06 & 0.24 & 0 & 1 & 0.05 & 0.22 & 0 & 1 & 0.05 & 0.21 & 0 & 1 \\
\hline & Educational Level 2 (High school) & 0.45 & 0.50 & 0 & 1 & 0.46 & 0.50 & 0 & 1 & 0.46 & 0.50 & 0 & 1 \\
\hline & Educational Level 3 (Junior college) & 0.25 & 0.43 & 0 & 1 & 0.16 & 0.37 & 0 & 1 & 0.16 & 0.36 & 0 & 1 \\
\hline & Educational Level 4 (University) & 0.22 & 0.41 & 0 & 1 & 0.30 & 0.46 & 0 & 1 & 0.30 & 0.46 & 0 & 1 \\
\hline & $\begin{array}{l}\text { Educational Level } 5 \text { (Graduate school } \\
\text { and higher) }\end{array}$ & 0.03 & 0.16 & 0 & 1 & 0.03 & 0.17 & 0 & 1 & 0.03 & 0.17 & 0 & 1 \\
\hline & Female $(=1)$ & 0.66 & 0.48 & 0 & 1 & 0.43 & 0.50 & 0 & 1 & 0.42 & 0.49 & 0 & 1 \\
\hline \multirow{3}{*}{ Dependent variables } & TAW experience $(=1)$ & 1.00 & 0.00 & 1 & 1 & 0.00 & 0.00 & 0 & 0 & 0.00 & 0.00 & 0 & 0 \\
\hline & PE (Permanent Employment) & 0.25 & 0.44 & 0 & 1 & 0.57 & 0.49 & 0 & 1 & 0.58 & 0.49 & 0 & 1 \\
\hline & Hourly wage (unit: yen) & 1325.73 & 843.39 & 529.63 & 5163.94 & 1702.81 & 2237.78 & 500.00 & 57377.05 & 1744.71 & 2225.21 & 500.00 & 57377.05 \\
\hline
\end{tabular}


Table 3 Estimation of the propensity score

\begin{tabular}{|c|c|c|c|c|}
\hline & \multicolumn{2}{|c|}{ Summer Vacation Homework } & \multicolumn{2}{|c|}{ Cleaning a Park } \\
\hline & (1) & (2) & (3) & (4) \\
\hline Discounting parameters & & & & \\
\hline$\beta$ & & $\begin{array}{l}-0.673 * * \\
(0.327)\end{array}$ & & $\begin{array}{l}-1.118 * \\
(0.657)\end{array}$ \\
\hline$\delta$ & $\begin{array}{l}-0.062 \\
(0.104)\end{array}$ & $\begin{array}{l}-0.108 \\
(0.109)\end{array}$ & $\begin{array}{l}-0.546 * \\
(0.293)\end{array}$ & $\begin{array}{l}-0.612 * * \\
(0.294)\end{array}$ \\
\hline Sign Effect & $\begin{array}{l}-0.581 \\
(1.268)\end{array}$ & $\begin{array}{l}-0.581 \\
(1.268)\end{array}$ & $\begin{array}{l}-1.209 \\
(1.312)\end{array}$ & $\begin{array}{l}-1.260 \\
(1.313)\end{array}$ \\
\hline Individual Characteristics & & & & \\
\hline $\begin{array}{l}\text { Household income } \\
\text { (excluding him/herself) }\end{array}$ & $\begin{array}{l}-0.049 \\
(0.037)\end{array}$ & $\begin{array}{l}-0.049 \\
(0.037)\end{array}$ & $\begin{array}{l}-0.041 \\
(0.038)\end{array}$ & $\begin{array}{l}-0.042 \\
(0.038)\end{array}$ \\
\hline Age & $\begin{array}{r}0.006 \\
(0.010)\end{array}$ & $\begin{array}{c}0.009 \\
(0.010)\end{array}$ & $\begin{array}{c}0.007 \\
(0.011)\end{array}$ & $\begin{array}{c}0.006 \\
(0.011)\end{array}$ \\
\hline $\begin{array}{l}\text { Household property (Land / } \\
\text { Housing) }\end{array}$ & $\begin{array}{c}0.008 \\
(0.005)\end{array}$ & $\begin{array}{c}0.008 \\
(0.005)\end{array}$ & $\begin{array}{c}0.008 \\
(0.005)\end{array}$ & $\begin{array}{c}0.008 \\
(0.005)\end{array}$ \\
\hline Household financial assets & $\begin{array}{l}-0.040 * * * \\
(0.013)\end{array}$ & $\begin{array}{l}-0.039 * * * \\
(0.013)\end{array}$ & $\begin{array}{l}-0.037 * * * \\
(0.013)\end{array}$ & $\begin{array}{l}-0.038 * * * \\
(0.013)\end{array}$ \\
\hline Household Housing Loans & $\begin{array}{l}-0.017 \\
(0.013)\end{array}$ & $\begin{array}{l}-0.017 \\
(0.013)\end{array}$ & $\begin{array}{l}-0.034 * * \\
(0.015)\end{array}$ & $\begin{array}{l}-0.033 * * \\
(0.015)\end{array}$ \\
\hline Household other debts & $\begin{array}{l}-0.003 \\
(0.052)\end{array}$ & $\begin{array}{l}-0.005 \\
(0.052)\end{array}$ & $\begin{array}{l}-0.006 \\
(0.057)\end{array}$ & $\begin{array}{l}-0.007 \\
(0.058)\end{array}$ \\
\hline Number of children & $\begin{array}{l}-0.032 \\
(0.109)\end{array}$ & $\begin{array}{l}-0.029 \\
(0.108)\end{array}$ & $\begin{array}{l}-0.146 \\
(0.116)\end{array}$ & $\begin{array}{l}-0.150 \\
(0.117)\end{array}$ \\
\hline Married (=1) & $\begin{array}{l}-0.520 * * \\
(0.264)\end{array}$ & $\begin{array}{l}-0.519 * \\
(0.266)\end{array}$ & $\begin{array}{l}-0.417 \\
(0.275)\end{array}$ & $\begin{array}{l}-0.413 \\
(0.275)\end{array}$ \\
\hline Educational Level & Controlled & Controlled & Controlled & Controlled \\
\hline $\operatorname{Female}(=1)$ & $\begin{array}{l}0.994 * * * \\
(0.233)\end{array}$ & $\begin{array}{l}1.026 * * * \\
(0.233)\end{array}$ & $\begin{array}{l}0.893 * * * \\
(0.237)\end{array}$ & $\begin{array}{l}0.904 * * * \\
(0.237)\end{array}$ \\
\hline Cons & $\begin{array}{l}-2.097 * * * \\
(0.790)\end{array}$ & $\begin{array}{l}-1.531 * \\
(0.840)\end{array}$ & $\begin{array}{l}-1.472 * \\
(0.734)\end{array}$ & $\begin{array}{l}-0.270 \\
(1.009) \\
\end{array}$ \\
\hline $\begin{array}{l}\text { Number of Observations } \\
\text { Log-Likelihood } \\
\text { LR statistic }\end{array}$ & $\begin{array}{r}1973 \\
-470.332 \\
54.44 * * * \\
\end{array}$ & $\begin{array}{r}1973 \\
-467.467 \\
60.17 * * * \\
\end{array}$ & $\begin{array}{r}1493 \\
-358.651 \\
57.99 * * * \\
\end{array}$ & $\begin{array}{r}1493 \\
-356.794 \\
61.71 * * * \\
\end{array}$ \\
\hline
\end{tabular}

Standard errors in parentheses; $* * * \mathrm{p}<0.01, * * \mathrm{p}<0.05, * \mathrm{p}<0.1$

Note: A proxy for hyperbolic discounting parameter $\beta$ used for the model (2) is imputed from the ratio of when respondents did homework (action) to when they planned doing it (plan). When we used the proxy calculated from the difference between action and plan, the parameter is still significant at $5 \%$ level (coefficient: -0.198 ; standard error: 0.082). When the sample is grouped by gender, the hyperbolic discounting parameters are still negatively significant among males (coefficient, -1.035 ; standard error, 
0.573), but not among females (coefficient, -0.467 ; standard error, 0.413). It implies the effect of individual time preferences work more strongly on male employees' probability of being in the TAW sector. Moreover, when we controlled for childhood and present time preferences together (correlation: hyperbolic discounting, -0.0058 ; exponential discounting, 0.0419), the effect of hyperbolic discounting of childhood remains significant (coefficient, -0.721 ; standard error, 0.359). This suggests that the childhood time preferences have a significant effect on the probability of engaging in temporary work with or without the control for the present time preferences. 
Table 4 Effect of TAW employment on transition probability and wage differences

\begin{tabular}{|c|c|c|c|c|c|}
\hline \multicolumn{6}{|c|}{ Transition Probability } \\
\hline & $\begin{array}{r}\text { Treated } \\
\text { Group }\end{array}$ & $\begin{array}{r}\text { Control } \\
\text { Group }\end{array}$ & ATT & Std. Err. & $\mathrm{T}$ value \\
\hline (i) & 238 & 2846 & -0.309 & 0.029 & -10.547 \\
\hline (ii) & 120 & 111 & -0.263 & 0.063 & -4.164 \\
\hline (iii) & 108 & 97 & -0.311 & 0.068 & -4.591 \\
\hline \multicolumn{6}{|c|}{ Hourly Wages } \\
\hline & $\begin{array}{r}\text { Treated } \\
\text { Group } \\
\end{array}$ & $\begin{array}{r}\text { Control } \\
\text { Group }\end{array}$ & ATT & Std. Err. & $\mathrm{T}$ value \\
\hline (i) & 238 & 2367 & -433.215 & 64.861 & -6.679 \\
\hline (ii) & 120 & 96 & 36.153 & 99.451 & 0.364 \\
\hline (iii) & 108 & 92 & 15.058 & 128.411 & 0.117 \\
\hline
\end{tabular}


Table 5 Long-term effects of TAW employment

\begin{tabular}{r|c|r|r|r|r|r}
\hline \multicolumn{7}{c}{ Transition Probability } \\
\hline \multirow{3}{*}{2009} & Time & Treated Group & Control Group & ATT & Std. Err. & T value \\
\cline { 2 - 7 } & $\mathrm{t}$ & 142 & 126 & -0.29 & 0.06 & -4.802 \\
\cline { 2 - 7 } & $\mathrm{t}+1$ & 142 & 123 & -0.217 & 0.062 & -3.512 \\
\cline { 2 - 8 } 2010 & $\mathrm{t}+2$ & 142 & 117 & -0.198 & 0.063 & -3.143 \\
\cline { 2 - 8 } & $\mathrm{t}+1$ & 120 & 111 & -0.263 & 0.063 & -4.164 \\
\hline \multirow{2}{*}{2011} & $\mathrm{t}$ & 120 & 99 & -0.138 & 0.067 & -2.064 \\
\hline & $\mathrm{7}$ & 124 & 111 & -0.356 & 0.061 & -5.885 \\
\hline \multirow{3}{*}{2009} & $\mathrm{~T}$ & Treated Group & Control Group & ATT & Std. Err. & T value \\
\cline { 2 - 8 } & $\mathrm{t}+1$ & 238 & 209 & -112.982 & 104.004 & -1.086 \\
\cline { 2 - 7 } & $\mathrm{t}+2$ & 238 & 182 & 146.576 & 143.535 & 1.021 \\
\hline \multirow{2}{*}{2010} & $\mathrm{t}$ & 238 & 160 & 44.738 & 99.31 & 0.45 \\
\cline { 2 - 7 } & $\mathrm{t}+1$ & 120 & 96 & 36.153 & 99.451 & 0.364 \\
\hline 2011 & $\mathrm{t}$ & 120 & 89 & -7.858 & 106.787 & -0.074 \\
\hline
\end{tabular}

Note: To control for individual heterogeneity in time preferences, the degree of impatience during childhood is used since the questions for each year is concerning the present time preferences under the hyperbolic discounting function, in a different way. 
Table 6 Effects of TAW employment by gender and age

\begin{tabular}{|c|c|c|c|c|c|}
\hline \multicolumn{6}{|c|}{ Transition Probability } \\
\hline \multicolumn{6}{|c|}{ Summer Vacation Homework $\beta, \delta$} \\
\hline & $\begin{array}{l}\text { Treated } \\
\text { Group }\end{array}$ & $\begin{array}{l}\text { Control } \\
\text { Group }\end{array}$ & ATT & Std. Err. & $\mathrm{T}$ value \\
\hline Whole Sample & 120 & 111 & -0.263 & 0.063 & -4.164 \\
\hline High propensity score region & 37 & 26 & -0.482 & 0.125 & -3.866 \\
\hline Male & 41 & 35 & -0.287 & 0.112 & -2.57 \\
\hline Female & 79 & 70 & -0.289 & 0.075 & -3.861 \\
\hline Oder than 60 & 17 & 10 & -0.25 & 0.161 & -1.553 \\
\hline Aged 60 and less & 103 & 94 & -0.143 & 0.07 & -2.043 \\
\hline Older than 52 & 36 & 33 & -0.029 & 0.103 & -0.286 \\
\hline Aged 52 and less & 84 & 71 & -0.217 & 0.082 & -2.66 \\
\hline Aged 40 and less & 36 & 28 & -0.41 & 0.13 & -3.149 \\
\hline \multicolumn{6}{|c|}{ Cleaning a Park $\quad \beta, \delta$} \\
\hline & $\begin{array}{l}\text { Treated } \\
\text { Group }\end{array}$ & $\begin{array}{l}\text { Control } \\
\text { Group }\end{array}$ & ATT & Std. Err. & $\mathrm{T}$ value \\
\hline Whole Sample & 108 & 97 & -0.311 & 0.068 & -4.591 \\
\hline High propensity score region & 43 & 36 & -0.321 & 0.11 & -2.925 \\
\hline Male & 40 & 37 & -0.315 & 0.11 & -2.869 \\
\hline Female & 68 & 55 & -0.13 & 0.085 & -1.531 \\
\hline Oder than 60 & 17 & 15 & -0.333 & 0.126 & -2.646 \\
\hline Aged 60 and less & 91 & 79 & -0.244 & 0.077 & -3.166 \\
\hline Older than 52 & 33 & 30 & -0.245 & 0.114 & -2.151 \\
\hline Aged 52 and less & 75 & 65 & -0.236 & 0.087 & -2.717 \\
\hline Aged 40 and less & 35 & 28 & -0.306 & 0.135 & -2.273 \\
\hline \multicolumn{6}{|c|}{ Hourly Wage } \\
\hline \multicolumn{6}{|c|}{ Summer Vacation Homework $\beta, \delta$} \\
\hline & \begin{tabular}{|l|} 
Treated \\
Group
\end{tabular} & \begin{tabular}{|l|} 
Control \\
Group
\end{tabular} & ATT & Std. Err. & $\mathrm{T}$ value \\
\hline Whole Sample & 120 & 96 & 36.153 & 99.451 & 0.364 \\
\hline High propensity score region & 37 & 23 & -8.226 & 157.127 & -0.052 \\
\hline Male & 41 & 35 & 0.737 & 319.474 & 0.002 \\
\hline Female & 79 & 63 & 1.558 & 103.165 & 0.015 \\
\hline Oder than 60 & 17 & 11 & -874.679 & 495.296 & -1.766 \\
\hline Aged 60 and less & 103 & 90 & -89.35 & 150.451 & -0.594 \\
\hline Older than 52 & 36 & 29 & -55.593 & 400.827 & -0.139 \\
\hline Aged 52 and less & 84 & 64 & -12.897 & 103.228 & -0.125 \\
\hline Aged 40 and less & 36 & 26 & 27.085 & 131.479 & 0.206 \\
\hline \multicolumn{6}{|c|}{ Cleaning a Park $\beta, \delta$} \\
\hline & $\begin{array}{l}\text { Treated } \\
\text { Group }\end{array}$ & $\begin{array}{l}\text { Control } \\
\text { Group }\end{array}$ & ATT & Std. Err. & $\mathrm{T}$ value \\
\hline Whole Sample & 108 & 92 & 15.058 & 128.411 & 0.117 \\
\hline High propensity score region & 38 & 27 & 54.402 & 152.541 & 0.357 \\
\hline Male & 40 & 33 & -1913.822 & 1750.449 & -1.093 \\
\hline Female & 68 & 47 & -58.111 & 104.706 & -0.555 \\
\hline Oder than 60 & 17 & 14 & -336.002 & 327.884 & -1.025 \\
\hline Aged 60 and less & 91 & 78 & 128.595 & 123.263 & 1.043 \\
\hline Older than 52 & 33 & 25 & -374.791 & 343.799 & -1.09 \\
\hline Aged 52 and less & 75 & 62 & -182.425 & 206.274 & -0.884 \\
\hline Aged 40 and less & 35 & 24 & -70.775 & 135.524 & -0.522 \\
\hline
\end{tabular}


Table 7 Mantel-Haenszel test statistics

\begin{tabular}{|c|c|c|c|c|}
\hline \multicolumn{5}{|c|}{ Probability of transition to permanent employment (2010) } \\
\hline & \multicolumn{3}{|c|}{ Summer Vacation Homework } & \multirow{2}{*}{$\begin{array}{c}\beta, \delta \\
\text { p_mh- }\end{array}$} \\
\hline Gamma & Q_mh+ & Q_mh- & $\bar{p}$ p_mh+ & \\
\hline 1 & 3.87824 & 3.87824 & 0.000053 & 0.000053 \\
\hline 1.05 & 4.06885 & 3.70478 & 0.000024 & 0.000106 \\
\hline 1.1 & 4.2434 & 3.53214 & 0.000011 & 0.000206 \\
\hline 1.15 & 4.41081 & 3.36769 & $5.10 \mathrm{E}-06$ & 0.000379 \\
\hline 1.2 & 4.5717 & 3.2107 & $2.40 \mathrm{E}-06$ & 0.000662 \\
\hline 1.25 & 4.72658 & 3.06053 & $1.10 \mathrm{E}-06$ & 0.001105 \\
\hline 1.3 & 4.87594 & 2.91659 & $5.40 \mathrm{E}-07$ & 0.001769 \\
\hline 1.35 & 5.02017 & 2.7784 & $2.60 \mathrm{E}-07$ & 0.002731 \\
\hline 1.4 & 5.15966 & 2.64551 & $1.20 \mathrm{E}-07$ & 0.004078 \\
\hline 1.45 & 5.29472 & 2.51753 & $6.00 \mathrm{E}-08$ & 0.005909 \\
\hline 1.5 & 5.42567 & 2.3941 & $2.90 \mathrm{E}-08$ & 0.008331 \\
\hline 1.55 & 5.55276 & 2.27492 & $1.40 \mathrm{E}-08$ & 0.011455 \\
\hline 1.6 & 5.67623 & 2.15969 & $6.90 \mathrm{E}-09$ & 0.015398 \\
\hline 1.65 & 5.79631 & 2.04816 & $3.40 \mathrm{E}-09$ & 0.020272 \\
\hline 1.7 & 5.9132 & 1.9401 & $1.70 \mathrm{E}-09$ & 0.026184 \\
\hline 1.75 & 6.02707 & 1.8353 & $8.30 \mathrm{E}-10$ & 0.033231 \\
\hline 1.8 & 6.13809 & 1.73356 & $4.20 \mathrm{E}-10$ & 0.041498 \\
\hline 1.85 & 6.24643 & 1.63471 & $2.10 \mathrm{E}-10$ & 0.051055 \\
\hline 1.9 & 6.35221 & 1.53858 & $1.10 \mathrm{E}-10$ & 0.061954 \\
\hline 1.95 & 6.45557 & 1.44502 & $5.40 \mathrm{E}-11$ & 0.074226 \\
\hline 2 & 6.55663 & 1.35391 & $2.80 \mathrm{E}-11$ & 0.087883 \\
\hline \multicolumn{5}{|c|}{ Cleaning a Park $\beta, \delta$} \\
\hline Gamma & Q_mh+ & Q_mh- & p_mh+ & p_mh- \\
\hline 1 & 4.04673 & 4.04673 & 0.000026 & 0.000026 \\
\hline 1.05 & 4.23106 & 3.88223 & 0.000012 & 0.000052 \\
\hline 1.1 & 4.39833 & 3.71685 & $5.50 \mathrm{E}-06$ & 0.000101 \\
\hline 1.15 & 4.55877 & 3.55934 & $2.60 \mathrm{E}-06$ & 0.000186 \\
\hline 1.2 & 4.71297 & 3.40899 & $1.20 \mathrm{E}-06$ & 0.000326 \\
\hline 1.25 & 4.86143 & 3.26518 & $5.80 \mathrm{E}-07$ & 0.000547 \\
\hline 1.3 & 5.00459 & 3.12737 & $2.80 \mathrm{E}-07$ & 0.000882 \\
\hline 1.35 & 5.14286 & 2.99507 & $1.40 \mathrm{E}-07$ & 0.001372 \\
\hline 1.4 & 5.27657 & 2.86787 & $6.60 \mathrm{E}-08$ & 0.002066 \\
\hline 1.45 & 5.40606 & 2.74538 & $3.20 \mathrm{E}-08$ & 0.003022 \\
\hline 1.5 & 5.53159 & 2.62727 & $1.60 \mathrm{E}-08$ & 0.004304 \\
\hline 1.55 & 5.65343 & 2.51323 & $7.90 \mathrm{E}-09$ & 0.005982 \\
\hline 1.6 & 5.7718 & 2.40299 & $3.90 \mathrm{E}-09$ & 0.008131 \\
\hline 1.65 & 5.88692 & 2.29631 & $2.00 \mathrm{E}-09$ & 0.010829 \\
\hline 1.7 & 5.99898 & 2.19296 & $9.90 \mathrm{E}-10$ & 0.014155 \\
\hline 1.75 & 6.10814 & 2.09273 & $5.00 \mathrm{E}-10$ & 0.018187 \\
\hline 1.8 & 6.21458 & 1.99545 & $2.60 \mathrm{E}-10$ & 0.022997 \\
\hline 1.85 & 6.31843 & 1.90094 & $1.30 \mathrm{E}-10$ & 0.028655 \\
\hline 1.9 & 6.41983 & 1.80904 & $6.80 \mathrm{E}-11$ & 0.035222 \\
\hline 1.95 & 6.51891 & 1.71962 & $3.50 \mathrm{E}-11$ & 0.042751 \\
\hline 2 & 6.61578 & 1.63255 & $1.80 \mathrm{E}-11$ & 0.051282 \\
\hline
\end{tabular}

Note: Gamma is log odds of differential assignment due to unobserved factors; Q_mh+ $(-)$ : Mantel-Haenszel statistic [assumption: overestimation (underestimation) of treatment effect]; $\mathrm{p} \_\mathrm{mh}+(-)$ : significance level [assumption: overestimation (underestimation) of treatment effect]. 
Table 8 Rosenbaum bounds

\begin{tabular}{|c|c|c|c|c|c|c|}
\hline \multicolumn{7}{|c|}{ Wage differences (2010) } \\
\hline \multicolumn{7}{|c|}{ Summer Vacation Homework $\beta, \delta$} \\
\hline Gamma & sig+ & sig- & t-hat+ & t-hat- & $\mathrm{CI}+$ & CI- \\
\hline 1 & 0.210814 & 0.210814 & 40.9836 & 40.9836 & -65.9836 & 158.197 \\
\hline 1.1 & 0.357605 & 0.106721 & 19.0164 & 68.5792 & -89.5025 & 186.066 \\
\hline 1.2 & 0.513926 & 0.049595 & -2.45892 & 91.6096 & -110.929 & 214.918 \\
\hline 1.3 & 0.656422 & 0.021497 & -22.0319 & 109.836 & -134.52 & 242.259 \\
\hline 1.4 & 0.771505 & 0.008803 & -40.0661 & 132.992 & -152.763 & 265.509 \\
\hline 1.5 & 0.855944 & 0.00344 & -59.7705 & 152.486 & -172.865 & 291.275 \\
\hline 1.6 & 0.913292 & 0.001293 & -75.4224 & 168.967 & -191.02 & 321.949 \\
\hline 1.7 & 0.94986 & 0.000471 & -88.7705 & 184.628 & -210.443 & 342.623 \\
\hline 1.8 & 0.971993 & 0.000167 & -102.254 & 203.989 & -225.978 & 365.984 \\
\hline 1.9 & 0.984819 & 0.000058 & -115 & 219.313 & -240 & 393.063 \\
\hline 2 & 0.991983 & 0.00002 & -129.892 & 236.943 & -259.264 & 414 \\
\hline \multicolumn{7}{|c|}{ Cleaning a Park $\beta, \delta$} \\
\hline Gamma & sig+ & sig- & t-hat + & t-hat- & $\mathrm{CI}+$ & CI- \\
\hline 1 & 0.085028 & 0.085028 & 72.4772 & 72.4772 & -31.3934 & 192.213 \\
\hline 1.1 & 0.16958 & 0.03662 & 51.7213 & 96.7844 & -54.0827 & 224.918 \\
\hline 1.2 & 0.281704 & 0.014715 & 29.4486 & 117.122 & -76.8033 & 255.373 \\
\hline 1.3 & 0.408655 & 0.005595 & 12.2951 & 138.907 & -96.1494 & 289.982 \\
\hline 1.4 & 0.535744 & 0.002035 & -6.50771 & 156.982 & -119.566 & 322.5 \\
\hline 1.5 & 0.651143 & 0.000714 & -22.5 & 177.5 & -137.523 & 349.69 \\
\hline 1.6 & 0.748005 & 0.000243 & -34.5753 & 198.907 & -153.962 & 381.5 \\
\hline 1.7 & 0.824255 & 0.000081 & -47.7049 & 217.437 & -173 & 406.795 \\
\hline 1.8 & 0.881178 & 0.000026 & -62.5228 & 236.202 & -189.566 & 434.542 \\
\hline 1.9 & 0.921831 & $8.40 \mathrm{E}-06$ & -75.9563 & 252.969 & -206.992 & 462.204 \\
\hline 2 & 0.949799 & $2.60 \mathrm{E}-06$ & -87.3179 & 273.5 & -221.721 & 491.514 \\
\hline
\end{tabular}

Note: Gamma: log odds of differential assignment due to unobserved factors, sig+ $(-)$ : upper (lower) bound significance level, t-hat $+(-)$ : upper (lower) bound Hodges-Lehmann point estimate, $\mathrm{CI}+(-)$ : upper (lower) bound confidence interval $(\mathrm{a}=.95)$ 
Summer vacation homework $(\beta, \delta)$

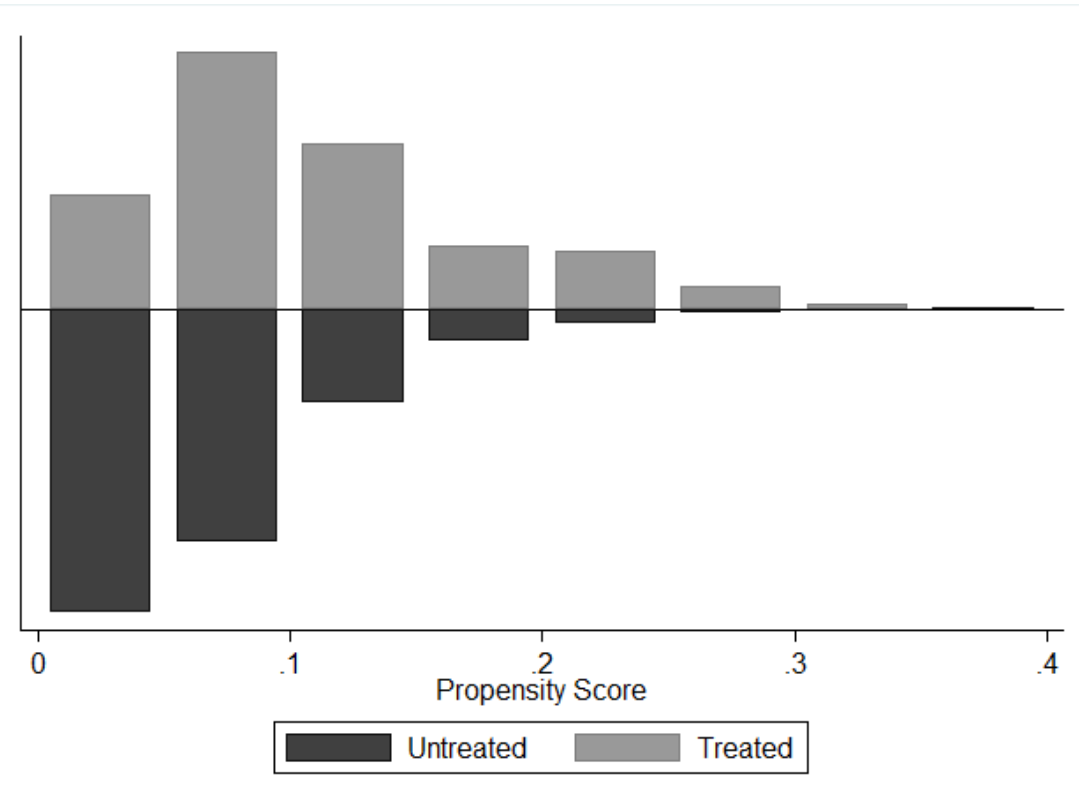

Cleaning a park $(\beta, \delta)$

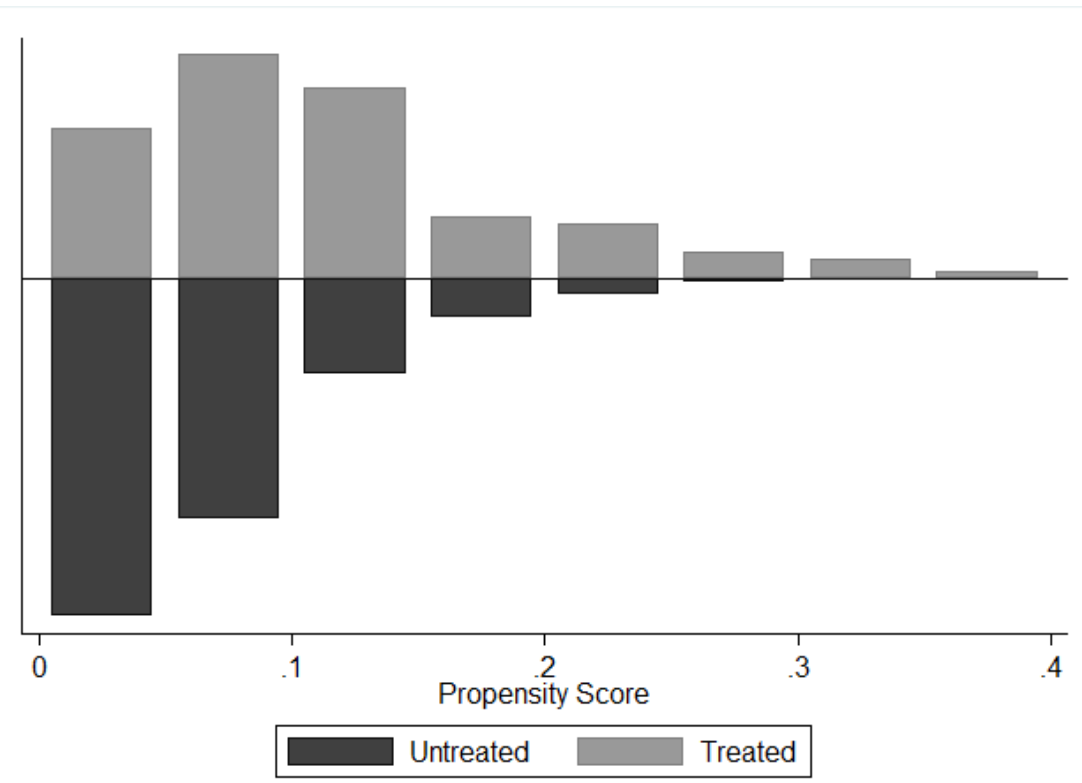

Figure 1 Histograms for propensity scores by treatment status 
Appendix 1 Data structure regarding career paths

A: 2 years ago $\rightarrow$ B: For the past 2 years $\rightarrow$ : The current status
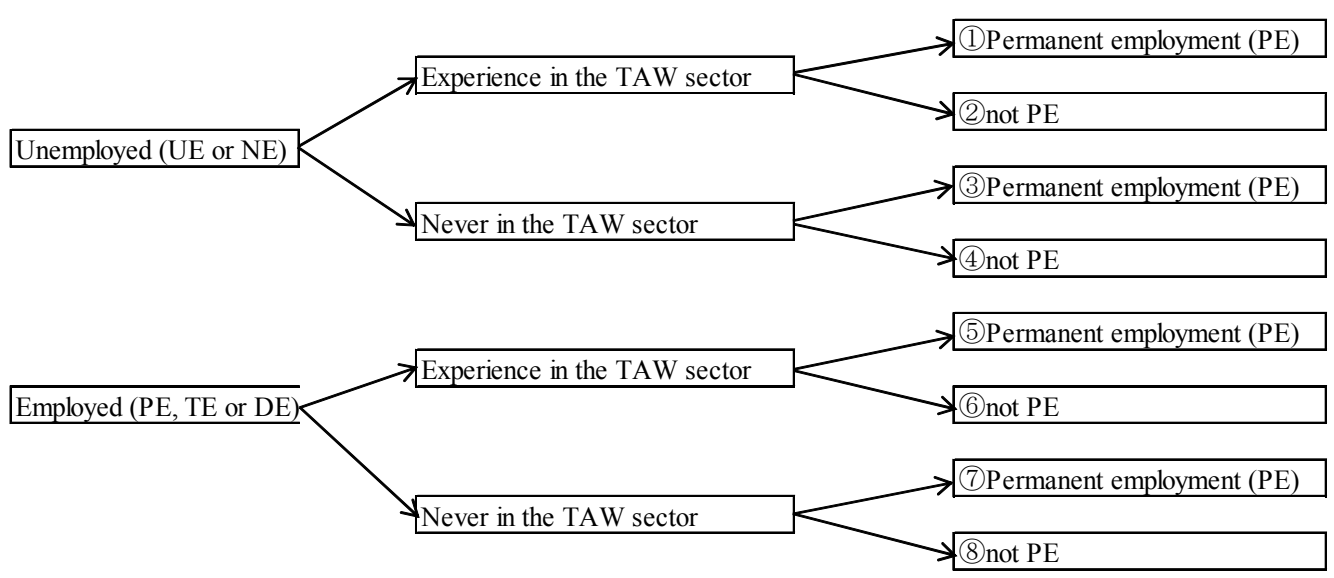
Appendix 2 Transition matrix of employment turnover

\begin{tabular}{|c|c|c|c|c|c|c|c|}
\hline $\begin{array}{l}\text { 2008-2011 } \\
\text { (Whole) }\end{array}$ & Permanent & Part-time & Dispatch & $\begin{array}{c}\text { Self- } \\
\text { employed } \\
\text { Family } \\
\text { businesses }\end{array}$ & Unemployed & $\begin{array}{c}\text { Not } \\
\text { employed } \\
\text { (no job } \\
\text { search) }\end{array}$ & Average Obs. \\
\hline Permanent & $90.6 \%$ & $4.2 \%$ & $0.2 \%$ & $1.7 \%$ & $1.5 \%$ & $1.8 \%$ & 1373.5 \\
\hline Part-time & $6.9 \%$ & $78.9 \%$ & $1.3 \%$ & $3.7 \%$ & $4.6 \%$ & $4.6 \%$ & 669 \\
\hline Dispatch & $7.1 \%$ & $30.4 \%$ & $48.6 \%$ & $0.0 \%$ & $9.3 \%$ & $4.6 \%$ & 33.75 \\
\hline $\begin{array}{l}\text { Self-employed } \\
\text { Family business }\end{array}$ & $4.8 \%$ & $5.5 \%$ & $0.0 \%$ & $83.3 \%$ & $1.6 \%$ & $4.8 \%$ & 525.25 \\
\hline Unemployed & $4.4 \%$ & $19.6 \%$ & $1.5 \%$ & $3.0 \%$ & $42.1 \%$ & $29.4 \%$ & 246 \\
\hline $\begin{array}{l}\text { Not employed } \\
\text { (no job search activities) }\end{array}$ & $2.0 \%$ & $3.4 \%$ & $0.1 \%$ & $2.0 \%$ & $6.2 \%$ & $86.2 \%$ & 912 \\
\hline $\begin{array}{l}2008-2011 \\
\text { (Male) }\end{array}$ & Permanent & Part-time & Dispatch & $\begin{array}{c}\text { Self- } \\
\text { employed } \\
\text { Family } \\
\text { businesses }\end{array}$ & Unemployed & $\begin{array}{c}\text { Not } \\
\text { employed } \\
\text { (no job } \\
\text { search) }\end{array}$ & Average Obs. \\
\hline Permanent & $91.9 \%$ & $3.5 \%$ & $0.2 \%$ & $1.4 \%$ & $1.6 \%$ & $1.5 \%$ & $\overline{\overline{1011}}$ \\
\hline Part-time & $13.2 \%$ & $68.5 \%$ & $3.4 \%$ & $3.3 \%$ & $4.5 \%$ & $7.1 \%$ & 148.75 \\
\hline Dispatch & $10.1 \%$ & $44.6 \%$ & $30.0 \%$ & $0.0 \%$ & $4.2 \%$ & $11.1 \%$ & 11.5 \\
\hline $\begin{array}{l}\text { Self-employed } \\
\text { Family business }\end{array}$ & $6.4 \%$ & $2.6 \%$ & $0.0 \%$ & $86.3 \%$ & $0.9 \%$ & $3.8 \%$ & 284.5 \\
\hline Unemployed & $7.2 \%$ & $12.6 \%$ & $2.6 \%$ & $3.5 \%$ & $43.2 \%$ & $30.8 \%$ & 74.75 \\
\hline $\begin{array}{l}\text { Not employed } \\
\text { (no job search activities) }\end{array}$ & $3.0 \%$ & $2.1 \%$ & $0.2 \%$ & $2.2 \%$ & $4.4 \%$ & $88.1 \%$ & 253.75 \\
\hline $\begin{array}{l}\text { 2008-2011 } \\
\text { (Female) }\end{array}$ & Permanent & Part-time & Dispatch & $\begin{array}{c}\text { Self- } \\
\text { employed } \\
\text { Family } \\
\text { businesses }\end{array}$ & Unemployed & $\begin{array}{c}\text { Not } \\
\text { employed } \\
\text { (no job } \\
\text { search) }\end{array}$ & Average Obs. \\
\hline Permanent & $87.1 \%$ & $6.2 \%$ & $0.4 \%$ & $2.5 \%$ & $1.4 \%$ & $2.4 \%$ & 362.5 \\
\hline Part-time & $5.0 \%$ & $81.9 \%$ & $0.8 \%$ & $3.9 \%$ & $4.6 \%$ & $3.8 \%$ & 520.25 \\
\hline Dispatch & $5.6 \%$ & $22.2 \%$ & $58.7 \%$ & $0.0 \%$ & $12.4 \%$ & $1.1 \%$ & 22.25 \\
\hline $\begin{array}{l}\text { Self-employed } \\
\text { Family business }\end{array}$ & $2.8 \%$ & $9.0 \%$ & $0.0 \%$ & $79.8 \%$ & $2.4 \%$ & $6.0 \%$ & 240.75 \\
\hline Unemployed & $3.1 \%$ & $22.7 \%$ & $1.1 \%$ & $2.7 \%$ & $41.6 \%$ & $28.7 \%$ & 171.25 \\
\hline $\begin{array}{l}\text { Not employed } \\
\text { (no job search activities) }\end{array}$ & $1.5 \%$ & $4.0 \%$ & $0.1 \%$ & $1.9 \%$ & $7.0 \%$ & $85.5 \%$ & 658.25 \\
\hline
\end{tabular}

